Beata Polanowska-Sygulska

\title{
Herkules w stajni niewspółmierności
}

Wzmożone promieniowanie anglosaskiej jurysprudencji jest dziś powszechnie obserwowalnym zjawiskiem. Charakterystyczne dla niej uwzględnianie w refleksji nad prawem szerszego, politycznego kontekstu znamionuje stopniowe odchodzenie od dominującej do niedawna na kontynentalnym gruncie tradycji analitycznej. U podłoża właściwego współczesnym przedstawicielom jurysprudencji przekonania o głębokim związku między filozofią prawa a filozofią polityczną leży przeświadczenie o współzależności obu tych dyscyplin od filozofii moralnej. Filozofia polityczna bowiem w świetle przyjętej przez nich perspektywy to filozofia moralna przeniesiona na grunt społeczny.

Swoistym ucieleśnieniem wspomnianych powiązań wydaje się znamienna droga intelektualna Josepha Raza, ucznia i następcy H. L. A. Harta na stanowisku profesora filozofii prawa na Uniwersytecie Oksfordzkim. Punktem wyjścia dla interdyscyplinarnej refleksji Raza była właśnie jurysprudencja; w tym obszarze jawi się on jako zdeklarowany zwolennik i obrońca twardego pozytywizmu, głoszącego tezę o możliwości ustalenia treści prawa poprzez wyłączne odniesienie do faktów społecznych, bez potrzeby odwoływania się do argumentów natury moralnej. Stricte filozoficznoprawne zainteresowania Raza ewoluowały z czasem w stronę ogólniejszej refleksji, wpisującej się w ramy filozofii politycznej. Głównym plonem tego etapu dociekań oksfordzkiego filozofa jest zaproponowana przez niego perfekcjonistyczna doktryna liberalna, konkurencyjna względem koncepcji Rawlsa. Stanowi ona oryginalną syntezę zasad liberalnych, niejako wychodzącą ponad główne kontrowersje, będące przedmiotem sporów między liberałami i komunitarystami. Najnowszym obszarem poszukiwań, wieńczącym intelektualną drogę Raza, jest filozofia moralna. W tej dziedzinie oksfordzki filozof jest zwolennikiem pluralizmu etycznego i obrońca przekonania o obiektywnym oraz uniwersalnym charakterze wartości, ugruntowanego w oryginalnej, kwestionującej inne stanowiska, argumentacji. Trzy dyscypliny, na styku których sytuują się zainteresowania Raza - filozofia prawa, filozofia polityczna i moralna - jego zdaniem oświetlają różne aspekty ludzkiego życia. Myśliciel opowiada się za zasadniczą jednością filozofii praktycznej; jego własne, interdyscyplinarne 
rozważania są niejako ilustracją tego wyznania wiary. W rozmowie ze mną, przeprowadzonej w Oksfordzie w 2010 r., Joseph Raz dał jawny wyraz wspomnianemu przekonaniu:

Wiele lat temu, zapewne na długo jeszcze przed powstaniem The Morality of Freedom, wątpiłem w to, jakoby sfera moralności tworzyła (czy też obejmowała) odrębny obszar rozważań, zasad czy wartości. [...] Engaging Reason to pierwsza książka, w której wysunąłem tezę, iż rozróżnienie rozważań moralnych i innych rozważań normatywnych ma charakter stylistyczny, kontekstualny, niemniej jest ono pozbawione jakiejkolwiek teoretycznej czy też praktycznej doniosłości ${ }^{1}$.

Zapytany o naturę dającej się zidentyfikować w jego dociekaniach charakterystycznej sekwencji gałęzi filozofii praktycznej, ukierunkowanej w stronę coraz ogólniejszej refleksji, odparł, że należy ją interpretować w kategoriach pewnego faktu biograficznego. Szerszy kontekst, do pewnego stopnia kwestionujący to wyznanie, znajdujemy w jednej z nowszych prac filozofa, zatytułowanej Value, Respect and Attachment. Ilustrując tezę o przenikaniu się dwóch wymiarów doświadczenia etycznego - obiektywnego i subiektywnego - Raz przywołuje znany fragment Małego Księcia, traktujący o traumatycznym przeżyciu bohatera, jakim było dla niego odkrycie ogrodu pełnego róż. Tam Mały Książę uświadomił sobie, że jego róża, wbrew składanym przez nią zapewnieniom, nie jest jedyna na świecie. Zgodnie z interpretacją Raza jest to „urocza opowieść o powszechnym doświadczeniu" ", wiążącym się z utratą złudzeń dzieciństwa i wejściem w dorosłość. Jest to moment, w którym uświadamiając sobie unikatowość właściwego nam, partykularnego i subiektywnego kontekstu, robimy decydujący krok w stronę tego, co ma wymiar obiektywny i uniwersalny ${ }^{3}$. Wówczas to doświadczamy nieodpartej siły rozumu i poddajemy się $\mathrm{jej}^{4}$. Wydaje się, że między zilustrowanym przez filozofa procesem przewartościowań, zachodzącym w trakcie dorastania, i jego własną drogą intelektualną zachodzi swoista paralela. Innymi słowy, charakterystyczna dla Raza ewolucja myślowej perspektywy, skierowana „od szczegółu do ogółu”, nie wydaje się li tylko przypadkowym faktem biograficznym, lecz - w pewnym aspekcie niejako prawidłowością. Żartobliwy autokomentarz na temat własnego oglądu stanowi następujące wyznanie filozofa, poczynione w znanym eseju Multiculturalism: „Moja praca to typowe zajęcie abstrakcjonisty (generalist), który potrafi mówić o wszystkim, nie mając pojęcia o niczym"s.

1 B. Polanowska-Sygulska, Rozmowy z oksfordzkimi filozofami, Kraków 2011, s. 256-257.

2 J. Raz, Value, Respect and Attachment, Cambridge 2001, s. 13.

3 Piszę na ten temat szerzej w monografii: B. Polanowska-Sygulska, Pluralizm wartości i jego implikacje w filozofii prawa, Kraków 2008, s. 327-328.

4 J. Raz, Value, Respect..., s. 14.

5 J. Raz, Multiculturalism, [w:] idem, Ethics in the Public Domain: Essays in the Morality of Law and Politics, Oxford 1994, s. 155. 
Powyższa ramowa charakterystyka sylwetki Josepha Raza jest pomyślana jako swoisty wstęp do dociekań, które utworzą trzon niniejszego opracowania. Będą one prowadzone $\mathrm{w}$ duchu podzielanego przez oksfordzkiego myśliciela przekonania o jedności filozofii praktycznej. W istotnym aspekcie zamierzam jednak wyjść poza perspektywę autora The Morality of Freedom. Stawiam tezę, że rozstrzygnięcia teoretyczne, dokonane czy to świadomie, czy też nie, na poziomie najgłębszej warstwy filozofii praktycznej - to jest filozofii moralnej - przekładając się na określoną koncepcję życia zbiorowego, wywierają decydujący wpływ na wizję prawa i jego stosowania.

Sięgnijmy do przemyśleń bodaj najbardziej wpływowego współczesnego filozofa prawa, jakim jest niedawno zmarły Ronald Dworkin. Z pozoru mogłoby się wydawać, że z racji przynależności do tej samej tradycji polityczno-prawnej poglądy Raza i Dworkina winny ze sobą blisko korespondować. Wszak obaj myśliciele bez najmniejszej wątpliwości wpisują się w szeroko rozumianą orientację liberalną. Niekwestionowanym przedstawicielem tego nurtu jest, jak wyżej wspomniano, Joseph Raz. Mimo wyraźnych, komunitarystycznych afiliacji, autor The Morality of Freedom jest nade wszystko zdeklarowanym zwolennikiem liberalnego $\mathrm{z}$ ducha ideału autonomii osobistej, który postrzega jako przystający do wymogów ery industrialnej, wraz z jej szybko zmieniającymi się technologiami i migracjami siły roboczej. Głoszony przezeń perfekcjonizm państwowy jest legitymizowany o tyle, o ile służy stwarzaniu warunków sprzyjających hołdowaniu przez obywateli autonomicznemu stylowi życia. Stąd przymus może być stosowany wyłącznie w celu ochrony autonomii.

Ronald Dworkin bez najmniejszych wątpliwości także jest kontynuatorem tradycji liberalnej. Jego dokonania są powszechnie interpretowane jako przynależne do wspomnianego nurtu. Zidentyfikowano go nawet jako ostatniego myśliciela „w linii wyznaczanej nazwiskami Johna Stuarta Milla i Johna Rawlsa"6. Jednoznacznie liberalnej proweniencji jest bowiem indywidualistyczna perspektywa, leżąca u podłoża zarówno jego doktryny, zbudowanej na fundamencie uprawnień (rights-based), jak i koncepcji demokracji, zakładającej ideę równego szacunku i równej ochrony obywateli (equal concern and respect). Co zastanawiające, właściwa Dworkinowi indywidualistyczna optyka mocno kontrastuje z charakterystycznym dla podejścia Raza antyindywidualizmem. Oksfordzki myśliciel jawnie deklaruje swoje stanowisko w tym względzie w swym kluczowym dziele The Morality of Freedom:

Jeżeli w przedstawionych w tej książce wywodach można wyróżnić jakiś motyw przewodni, to jest nim wyrażona w niej krytyka indywidualizmu oraz próba argumentacji za moralnością liberalną, opartą na nieindywidualistycznych podstawach. Indywidualizm, bądź indywidualizm moralny w rozumieniu tej książki, to doktryna, zgodnie z którą wyłącznie stany odnoszące się do indywidualnych istot ludzkich, bądź do aspektów ich życia, mogą być same w sobie dobre lub wartościowe $[\ldots]^{7}$.

\footnotetext{
6 W. Sadurski, Śmierć giganta, „Gazeta Wyborcza”, 23.02.2013, s. 29.

7 J. Raz, The Morality of Freedom, Oxford 1986, s. 18.
} 
Ów charakterystyczny dla Raza anty-indywidualistyczny rys unaocznia jego koncepcja społecznego uwarunkowania wartości, a także dokonane przezeń rozpoznanie dóbr kolektywnych (collective goods) jako wartości samych w sobie. Obaj myśliciele - Dworkin i Raz - zdają się zatem zajmować opozycyjne stanowiska $\mathrm{w}$ obrębie tego samego, szeroko rozumianego nurtu w zakresie filozofii politycznej, hołdując przeciwstawnym wizjom państwa: $\mathrm{z}$ jednej strony jego neutralności względem różnych koncepcji dobra, z drugiej zaś - jego perfekcjonizmowi. Pomimo tej bogatej w konsekwencje różnicy, przynależą do wspólnej, liberalnej tradycji.

Tym bardziej zaskakuje odmienność przyjętych przez nich perspektyw na poziomie filozofii prawa. Mogłoby się po raz kolejny wydawać, iż wspólne korzenie - obaj wszak czerpią z dziedzictwa anglosaskiej jurysprudencji - przesądzą o podobnym oglądzie. Co istotne, obaj myśliciele reprezentują pokrewny styl refleksji nad prawem, sytuując ją w szerokim kontekście politycznym i moralnym. Jednakże właściwe im wizje stosowania prawa radykalnie od siebie odbiegają. Jak wspomniano powyżej, Raz zawrócił z drogi swojego mistrza Harta w stronę wyrafinowanego pozytywizmu, opowiadając się zdecydowanie za „twardą" wersją tego stanowiska. Dworkin, także odcinając się od Harta, zaproponował całkowicie nowe podejście w jurysprudencji, przekraczające tradycyjną opozycję między pozytywizmem a prawem natury. Jego nader wpływowa koncepcja law as integrity zrywa $\mathrm{z}$ wizją prawa jako gotowego obiektu, podkreślając jego interpretacyjny wymiar. Tym samym kładzie szczególny akcent na rolę sędziów, zyskujących w Dworkinowskim „imperium prawa" status książąt. Rozbieżne punkty widzenia obu myślicieli zdają się stanowić modelową ilustrację maksymy: „Wiek XX to czas władzy parlamentów, zaś wiek XXI to czas władzy sędziów". W tym aspekcie twardy pozytywizm Raza sytuuje go w wieku XX, zaś interpretacyjna filozofia prawa Dworkina lokuje go zdecydowanie w wieku XXI. Nasuwa się kluczowe pytanie: na jakiej płaszczyźnie należy poszukiwać źródeł wspomnianego rozziewu? Nie wydaje się, by poziom filozofii politycznej oferował rozstrzygającą odpowiedź. Mimo wszelkich różnic między wizjami państwa wyłaniającymi się z refleksji Raza i Dworkina, ich stanowiska względem kluczowej kwestii relacji między prawami jednostki a dobrem wspólnym nie są od siebie zbyt odległe. Obaj bowiem wpisując się w tradycję liberalną - mocno podkreślają priorytet jednostki przed wspólnotą (jakkolwiek odmiennie rozkładają akcenty). Być może zatem punkt ciężkości usytuowany jest głębiej, na poziomie fundamentalnych rozstrzygnięć w obszarze filozofii moralnej, przekładających się następnie na wizję polityki, prawa i jego stosowania.

Stawiam tezę, iż kardynalna rozbieżność między stanowiskami Raza i Dworkina w jurysprudencji jest bezpośrednią konsekwencją odmiennych optyk, właściwych obu myślicielom na poziomie filozofii moralnej. Zaryzykowałabym również twierdzenie, że przy wszystkich zastrzeżeniach, jakie można skierować 
pod adresem perspektywy Josepha Raza w obszarze szeroko rozumianej filozofii praktycznej, wyznawany przez niego pluralizm etyczny stanowi świetną lekcję pokory dla prawników, odsłaniając równocześnie niebezpieczeństwa, uwikłane w opozycyjnym, Dworkinowskim podejściu.

Zestawienie poglądów obu filozofów, sytuujących się na poziomie filozofii moralnej, wymaga choćby ramowej prezentacji specyficznego stanowiska Josepha Raza. Podzielany przez niego pluralizm wartości jest niejako pośrednim poglądem na mapie teorii etycznych, dystansującym się zarówno od monizmu, jak i relatywizmu, i proponującym unikatowy, odmienny od obu powyższych punktów widzenia opis życia etycznego. Koncepcje monistyczne zakładają istnienie jednego możliwego do przyjęcia systemu wartości; rozmaite odmiany etycznego subiektywizmu czy relatywizmu przyjmują, iż wszystkie wartości są wyrazem preferencji czy konwencji. Na gruncie pluralizmu fundamentalne ludzkie wartości są obiektywne i poznawalne, ale jest ich wiele. Owa wielość nie poddaje się ani redukcji, ani pełnemu hierarchicznemu uporządkowaniu, które byłoby uniwersalnie prawomocne. Nie sposób łączyć ze sobą pewnych wartości; niektóre spośród nich bywają niewspółmierne. W interpretacji Raza wspomniane zjawisko niewspółmierności wartości, którego rozpoznanie jest wyróżniającym rysem pluralistycznej perspektywy w etyce, zasadza się na ich nieporównywalności (braku wspólnej miary). Nie istnieje żaden ostateczny standard, który pozwoliłby na racjonalne rozstrzyganie kolizji między nimi. Wizja, która wyłania się z pluralistycznego oglądu, to świat będący areną nieuniknionych zderzeń, dylematów moralnych i utraty, która towarzyszy koniecznym wyborom między kolidującymi wartościami. To rzeczywistość, w której z założenia nie można mieć wszystkiego; w której nie wchodzi w grę ani osiągnięcie harmonii, ani znalezienie jakiegoś „ostatecznego rozwiązania” ludzkich problemów. Wreszcie to świat na trwałe naznaczony brakiem, cierpieniem i możliwością tragedii.

Światowa dyskusja nad tą zrodzoną w Oksfordzie kontrowersyjną koncepcją i jej implikacjami dla filozofii politycznej i filozofii prawa rozwinęła się w ciągu ostatnich kilkunastu lat. Strumień publikacji poświęconych pluralizmowi nasilił się po wydaniu w 1995 r. głośnej książki Johna Graya, zatytułowanej Isaiah Berlin. Autorstwo koncepcji pluralizmu etycznego przypisuje się bowiem powszechnie Isaiahowi Berlinowi, jakkolwiek zarówno on sam, jak i inni autorzy upatrują jej źródeł w poglądach całej plejady dawniejszych myślicieli. Ujmując rzecz w największym skrócie, można uznać późne lata 80. i wczesne 90. ubiegłego wieku za okres, w którym miało miejsce niejako „ukonstytuowanie się” pluralizmu wartości jako niezależnego kierunku, stanowiącego źródło inspiracji dla rosnącej liczby autorów ${ }^{8}$.

8 Miałam przywilej bycia świadkiem, a zarazem - do pewnego stopnia - uczestniczką tamtych dyskusji. Zob. I. Berlin, B. Polanowska-Sygulska, Unifinished Dialogue, Amherst-New York 2006, s. 211-229. 
Joseph Raz jest autorem niejako równoległej względem Berlinowskiej, a zarazem najbardziej wyrafinowanej i rozwiniętej teoretycznie wersji pluralizmu. Jej wyróżniającym rysem jest charakterystyczna dla ujęcia Raza tzw. teza o społecznej zależności wartości, tj. przekonanie o ich zależności od społecznych praktyk. Warto odnieść się do pewnego wybranego wątku rozważań Raza, który ma istotne znaczenie dla filozofów prawa. Otóż jednym z argumentów, wysuwanych przez Raza za tezą o społecznej zależności szeroko zakrojonych celów (comprehensive goals), czyli takich, które wywierają wpływ na wiele aspektów ludzkiego życia, jest fakt, iż jednostki nie byłyby w stanie zakładać ani realizować owych celów inaczej, niż tylko poprzez ciągłe zaznajamianie się z formami społecznymi. Innymi słowy - jednostki nie są w stanie urzeczywistniać niektórych celów dzięki świadomemu poddaniu ich gruntownym przemyśleniom. Mogą one być osiągnięte wyłącznie poprzez nabranie stosownych nawyków (habituation). Raz przywołuje tu przykład tzw. „gęstych” relacji, jakie zachodzą między rodzicami a dziećmi, czy też między małżonkami. Ich treść jest na tyle bogata, że znacznie wykracza poza teoretycznie możliwy opis, jaki bylibyśmy w stanie skonstruować. Stosunkowo adekwatną rekonstrukcję tego rodzaju stosunków międzyludzkich mogą zaoferować jedynie wybitne dzieła sztuki. Nie sposób nauczyć się pielęgnowania takich relacji, zgłębiając ich sformułowaną explicite charakterystykę; w grę wchodzi wyłącznie doświadczenie. Nawet wtedy, gdy już udało nam się przyswoić odpowiednie wzorce zachowań, większość naszych poczynań zasadza się na wyuczonych, na poły automatycznych reakcjach. Przy pewnym nakładzie sił jesteśmy w stanie je stłumić, ale z reguły nie poddajemy ich świadomej refleksji i nie do końca zdajemy sobie z nich sprawę. Nawet wówczas, gdy nasze reakcje mogłyby być świadome, to jednak nie powinny takimi być. Przywiązujemy wagę do ich spontaniczności i niejako instynktownej bezpośredniości. Ich doniosłość zasadza się właśnie na tym, że nie są przez nas w pełni kontrolowane. Rzecz komplikuje się dodatkowo wtedy, gdy urzeczywistnienie danego celu zależy od interakcji między ludźmi. Wiele zależy wówczas od tego, czy partnerzy potrafią właściwie odczytywać znaczenie swoich zachowań. W grę wchodzi wówczas również tzw. język ciała, czyli tysiące drobnych sygnałów, jakie ludzie sobie nieświadomie przekazują ${ }^{9}$. Filozof przekonująco argumentuje za społecznym ugruntowaniem owych szeroko zakrojonych celów, rzucając światło na ich złożoną naturę:

Fundamentalne opcje, które nadają naszemu życiu znaczenie - rozmaite zawody, które możemy uprawiać, przyjaźnie i relacje, jakie możemy nawiązywać, przejawy lojalności i zaangażowania, w jakie wchodzimy i które rozwijamy, nasze zainteresowania kulturalne, sportowe czy jakiekolwiek inne - wszystkie one są gęstymi sieciami złożonych działań i interakcji. Są otwarte tylko dla tych, którzy je doskonalą; niemniej ich złożoność i gęstość uwikłanych szczegółów

9 Piszę na ten temat także w książce: B. Polanowska-Sygulska, Pluralizm wartości..., s. $116-118$. 
uniemożliwia ich świadome przyswojenie czy też sformułowanie ich szczegółowej charakterystyki. Są one dostępne tylko dla tych, którzy posiadają praktyczną wiedzę na ich temat bądź mogą ją zdobyć; wiedzę wyrażaną przez praktyki społeczne i przekazywaną poprzez nabieranie stosownych nawyków ${ }^{10}$.

Poddając pod rozwagę filozoficznoprawne implikacje optyki Josepha Raza, przywołajmy autentyczny postulat, wysunięty kilka lat temu w trakcie debaty nad nowo powstającą konstytucją Ekwadoru, przez pewną posłankę hołdującą radykalnie feministycznym przekonaniom. Zaproponowała ona wpisanie do opracowywanego wówczas projektu ekwadorskiej ustawy zasadniczej prawa do orgazmu. Taka regulacja stanowiłaby podstawę umożliwiającą kobietom dochodzenie prawa do satysfakcji seksualnej na drodze sądowej ${ }^{11}$. Refleksja Josepha Raza w pełni odsłania absurdalność tego pomysłu. Nie ma chyba obszaru relacji międzyludzkich, który byłby - mówiąc językiem Raza - „gęstszy”, a tym samym trudniejszy $\mathrm{w}$ opisie i $\mathrm{w}$ mniejszym stopniu poddający się racjonalnym decyzjom czy rozstrzygnięciom. Tym samym niedorzecznością jest zamysł poddawania wspomnianej sfery jurysdykcji sądowej. Co więcej, w świetle sformułowanej przez Raza miażdżącej krytyki moralności opartej na uprawnieniach (rights-based morality), a zarazem proceduralnego liberalizmu, idea postrzegania relacji międzyludzkich w kategoriach uprawnień jawi się z samej swej natury jako nieoddająca sprawiedliwości bogactwu doświadczenia etycznego i tym samym $\mathrm{z}$ gruntu chybiona.

Zupełnie inaczej kwestie te przedstawiają się na gruncie optyki Dworkina. Wysunięty przez amerykańskiego filozofa postulat, ,wzięcia praw poważnie” jest wyrazem opozycyjnego względem perspektywy Raza stanowiska w kwestii moralności opartej na uprawnieniach. Innymi słowy, w przeciwieństwie do Raza Dworkin postrzega relacje międzyludzkie właśnie w kategoriach uprawnień i płynących z nich obowiązków. Wyobraźmy sobie sytuację, w której dochodzi do uwzględnienia w hipotetycznej konstytucji wspomnianego wcześniej uprawnienia. Dworkinowski „książę prawa” - to jest idealny sędzia, noszący skromne miano Herkulesa - dysponuje niedostępną zwykłym śmiertelnikom wiedzą i doświadczeniem. Dzięki nim, jak celnie pisze M. Zirk-Sadowski, jest on „W stanie uchwycić całość uwarunkowań społecznych i politycznych występujących w danej wspólnocie politycznej, rozpoznać zasady rządzące tą społecznością, wyważyć je i tą drogą dojść do «jednej jedynej słusznej odpowiedzi» na pytanie o uprawnienia jednostki"'12. Wkracza zatem wyposażony w swoistą piłe tarczową na zaminowany grunt delikatnych relacji międzyludzkich i - jeśli ma do czynienia z rozwiniętym systemem prawnym, obfitującym w bogate źródła

${ }^{10}$ J. Raz, Multiculturalism, s. 162.

${ }^{11}$ Zob. M. Tryc-Ostrowska, Konstytucyjne prawo do orgazmu, „Rzeczpospolita”, 6.05.2008, s. A15. Wspomniany postulat ostatecznie nie został uwzględniony w konstytucji Ekwadoru.

${ }^{12}$ M. Zirk-Sadowski, Wprowadzenie do filozofii prawa, Kraków 2000, s. 212. 
prawa oraz materiał orzeczniczy - dokonuje uwieńczonej sukcesem wiwisekcji normatywnych struktur społecznych, prowadzącej do identyfikacji jednego jedynego słusznego rozstrzygnięcia. Nie jest przy tym, jak jego pozytywistyczny przeciwbiegun noszący miano Herberta, związany opinią większości; kieruje się własnym osądem, bazując na posiadanej przez siebie wiedzy i doświadczeniu. Jest to zadanie na miarę antycznego herosa - tylko „książęta prawa” są predestynowani do oczyszczenia imperium, w którym sprawują autentyczną władzę, z rzekomo niewspółmiernych kolizji uprawnień.

Fundamentem tego rodzaju optyki jest przeświadczenie o istnieniu zintegrowanego systemu wartości, innymi słowy - monizm etyczny, przy wszystkich zastrzeżeniach i całym wyrafinowaniu charakteryzującym Dworkinowskie ujęcie. Filozof jawnie deklaruje swoje przekonania w tym względzie w swej przedostatniej pracy, zatytułowanej Justice for Hedgehogs. Pierwsze zdanie tego obszernego credo Dworkina brzmi: „Ta książka broni rozległej, starej tezy filozoficznej o jedności wartości".

Rozziew między stanowiskami Raza i Dworkina w jurysprudencji sięga zatem swymi korzeniami poziomu filozofii moralnej. Konsekwencje pluralistycznego oglądu, które dla Raza są wyrazem bogactwa i złożoności ludzkiego doświadczenia etycznego, Dworkinowi przywodzą na myśl wymagające oczyszczenia stajnie Augiasza. To, co zdaniem Raza odsłania granice ludzkiego rozumu, wedle Dworkina stanowi wyzwanie dla współczesnych herosów, czyli wyposażonych w niemal nadludzkie predyspozycje sędziów. Nieunikniony konflikt niewspółmiernych wartości, który zdaniem Raza oferuje mocny argument za rozwiązywaniem głęboko spornych kwestii za pomocą uregulowań legislacyjnych, ze swej natury dopuszczających kompromis i polityczne renegocjacje, w przekonaniu Dworkina winien być wpisany w ramy „uprawnieniowej” wizji polityki (rights-based) i tym samym poddany jurysdykcji sądów. W efekcie, zgodnie z duchem XXI w., pogłębia się proces przesunięcia mocy decyzyjnej z parlamentów do sądów.

Tę tendencję $\mathrm{z}$ wielu względów uważam za niepokojąca; tym cenniejsza zdaje się lekcja pokory dla prawników, płynąca z wnikliwych dociekań Josepha Raza i innych pluralistów etycznych, z Isaiahem Berlinem i Johnem Grayem na czele. 